\title{
ASSOCIATION BETWEEN KNOWLEDGE, ATTITUDE, AND ADHERENCE TO APPLY CORRECT DRUG INJECTION
}

\author{
Surya Darmawan, Elsye Maria Rosa, Merita Arini \\ Masters Program in Hospital Management, \\ Muhammadiyah University at Yogyakarta
}

\begin{abstract}
Background: Good performance of nurses at hospital is essential for patient safety and prevention of adverse events. It is possible for nurses at work to make unintended error. Error in providing medicine can result in serious problem, ranging from mild injury to severe injury or even death. This study aimed to determine the association between knowledge, attitude, and adherence to apply correct drug injection among nurses at Islamic Hospital, Surakarta.

Subjects and Method: This was a mixed method study, conducted at Islamic Hospital, Surakarta. A sample of 130 nurses were selected for the quantitative study by random sampling. Informants for the qualitative study included nurses and managers who were responsible for drug and administration regulation. The dependent variable was adherence to correct drug injection. The independent variables were knowledge and attitude. The qualitative data were collected by in-depth interview, questionnaire, and observation.
\end{abstract}

Results: Knowledge and attitude regarding correct drug injection were good enough among nurses at Islamic Hospital, Surakarta. With respect to nurse adherence to correct drug injection, $56.92 \%$ showed route correct, $56.15 \%$ showed time correct, $50.77 \%$ showed document correct, $26.92 \%$ showed dose correct, 22.31\% showed drug correct. Linear regression analysis showed association between knowledge, attitude, and correct drug injection. Problems identified included suboptimal implementation of standard operating procedure, job duplication between different profesional, lack of supervision and evaluation on the implementation of correct drug injection.

Conclusion: Implementation of correct drug injection is still substandard. There is a need to improve nurse adherence by implementing routine supervision with clear policy on the job description on each profession.

Keywords: correct drug injection, nurse, knowledge, attitude

Correspondence: Surya Darmawan. Masters Program in Hospital Management, Muhammadiyah University at Yogyakarta, Yogyakarta.

Email: suryadrtarua82@yahoo.com. 